\title{
List of abbreviations and conventions
}

\section{SELECTED WORKS BY FILMER (POLITICAL)}

AN The Anarchy of a Limited or Mixed Monarchy, in J. P. Sommerville (ed.), Robert Filmer. Patriarcha and Other Political Writings (Cambridge, 1991), pp. 131-71.

DO Directions for Obedience to Governours in Dangerous and Doubtfull Times, in Sommerville (ed.), Patriarcha, pp. 281-6.

FH The Free-holders Grand Inquest Touching Our Sovereraigne Lord the king and His Parliament, in Sommerville (ed.), Patriarcha, pp. 69-130.

OA Observations Upon Aristotles Politiques Touching Forms of Government, in Sommerville (ed.), Patriarcha, pp. 235-81.

OG Observations Concerning The Originall of Goverment, Upon Mr Hobs Leviathan, Mr Milton against Salmasius, H. Grotius De Jure Belli, in Sommerville (ed.), Patriarcha, pp. 184-234.

PT Patriarcha or The Naturall Power of Kinges Defended against the Unnatural Liberty of the People, in Sommerville (ed.), Patriarcha, pp. 1-68.

\section{SELECTED WORKS BY FILMER (OTHERS)}

$A D$ An Advertisement to the Jurymen of England, Touching Witches. Together with A Difference between An English and Hebrew Witch (edition printed from the original manuscript by The Rota, at the University of Exeter, 1975).

BHG Of the Blasphemie against the Holy-Ghost (London, 1647).

QQ Quaestio Quodlibetica or A Discourse, Whether it may bee Lawfull to take Use For Money (London, printed for Humphrey Moseley, 1653).

VW 'In Praise of the Vertuous Wife', in M. Ezell, The Patriarch's Wife. Literary Evidence and the History of the Family (Chapel Hill and London, 1987), Appendix I, pp. 169-90.

\section{OTHER ABBREVIATIONS}

BDO Bodleian Library, Oxford

BL British Library, London

CCL Canterbury Cathedral Library

DNB Dictionary of National Biography

EEBO Early English Books Online

EHR English Historical Review

HJ Historical Journal

HPT History of Political Thought 


\section{List of abbreviations and conventions}

JBS Journal of British Studies

KAO Kent Archive Office, Maidstone

ODNB Oxford Dictionary of National Biography (new edition online)

OED Oxford English Dictionary

PP 1610 E. Read Foster (ed.), Proceedings in Parliament 1610 (New Haven and London, 2 vols., 1966), vols i and ii

PP 1628 R. C. Johnson et al. (eds), Proceedings in Parliament 1628 (New Haven and London, 6 vols., 1977-83), vols ii, iii, vi (Appendixes and Indexes)

PRO Public Record Office, London

\section{PLACES OF PUBLICATION}

The place of all publications is London unless otherwise stated.

\section{DATES}

All dates are given with the year beginning on 1 January.

\section{TITLES}

Titles of primary sources are given in short when they are too long and when this does not compromise their general meaning. Titles of secondary sources have been capitalised. The name of authors of primary sources is given in full, whilst only the initials and the surname are provided in the case of secondary literature.

\section{TRANSLATIONS AND SPELLING}

Translations of non-English sources that have no English edition are the author's own. The notes direct the reader to the original text.

\section{MANUSCRIPTS}

Recto and verso of manuscript pages are indicated both by 'r'-'v' and by 'a'-'b'. 
Everything has been said before. But since nobody listens we have to keep going back and begin again. (André Gide, Le traité du Narcisse, 1891) 
Cesare Cuttica - 9781784992279 Downloaded from manchesterhive.com at 04/26/2023 08:52:39AM via free access 